\title{
Study on the Role of Technological Innovation in Business Administration
}

\author{
Haixing Ni \\ B\&R Technology Co., Ltd., Fuzhou, China \\ Email: mlbsabc@sina.com
}

How to cite this paper: Ni, H.X. (2018) Study on the Role of Technological Innovation in Business Administration. Modern Economy, 9, 1619-1624.

https://doi.org/10.4236/me.2018.910100

Received: September 12, 2018

Accepted: October 7, 2018

Published: October 10, 2018

Copyright (C) 2018 by author and Scientific Research Publishing Inc. This work is licensed under the Creative Commons Attribution International License (CC BY 4.0).

http://creativecommons.org/licenses/by/4.0/

\begin{abstract}
With China's economic development and social progress, China has made great achievements in business administration, and companies in China have grown rapidly. At the same time, companies also face a variety of challenges. While, business administration can enable companies to develop rapidly. Innovative business management could give full of vitality to the development of enterprises. And it has become the trend today. This paper first expounds the current development status of enterprise business management, then analyzes the role of technological innovation in business management, then discusses the strategies of the application of scientific and technological innovation in three aspects, that is, increasing the emphasis on the application of scientific and technological innovation, strengthening the cultivation of talents, and increasing the financial investment of scientific and technological innovation. At last, taking Xiaomi as an example, this paper analyzes the importance of technological innovation in business management. Innovation in business management science and technology can effectively make enterprises sustainable development.
\end{abstract}

\section{Keywords}

Business Management, Full of Vitality, Technological Innovation, Development of Enterprises

\section{Introduction}

The market competition in the current stage is more and more intense. In order to seize the initiative in the fierce market competition, enterprises must pay attention to the application of technological innovation, improved the level of scientific and technological innovation of enterprises comprehensively through the application of diversified measures and improve the innovation mechanism 
of science and technology in the enterprise. In the process of using scientific and technological innovation, some problems will inevitably arise. It is necessary for enterprises to take corresponding measures to give full play to the advantages of scientific and technological innovation in business management. In addition, enterprises can not only achieve self-development but also can promote the development and progress of society by using scientific and technological innovation technology and combining results with actual production [1].

In recent years, Chinese enterprises have achieved rapid developments. During this period, the market economic form under the development of market changes has also been studied. Many enterprises have adjusted the management mode to some extent, and also carried out the exploration to the business administration main body construction. However, from the actual situation analysis, the business management model is still relatively old-fashioned, which cannot meet the requirements of society and market for enterprises, and do not accord with the requirement of economic globalization to enterprise. The main cause of this problem is the enterprise itself. In the process of business management, enterprises are too influenced by the traditional management mode, and there is no emphasis on the connection between business management and market competition. As a result, the enterprise's ability to control the market is insufficient.

For enterprise development, business management is the key source for keeping its operation. Good business management can promote the enterprise to achieve sustainable development. However, problems in business management will affect the development of enterprises. In order to enable enterprises to achieve sustainable development in the market economy environment, it is necessary to constantly update business management concepts. Only in this way can business management be guaranteed to adapt to social competition, and companies be allowed to stand out among competitors. However, the concept of business administration in some Chinese enterprises is still backward. In particular, traditional enterprises often ignore the update of management concepts when they carry out business management. The lack of recognition of the importance of renewal has hampered the development of enterprises.

At present, more China's enterprises choose relatively new operating structure (as shown in Figure 1) in the process of running business management projects, which can realize the effective allocation and control of enterprise resources. In the structure of enterprise resources, the capital that the enterprise can flow and project management mode are all necessary elements. They can carry on centralized application of the enterprise capital, and can make sure the market activity of the enterprise and economic activity realize better development. However, some enterprises still follow the traditional management mode, or simply imitate the excellent experience and have not concluded suitable management mechanism for themselves. The lack of impetus in the reform and innovation path will even affect the economic benefits of enterprises and even restrict the long-term 


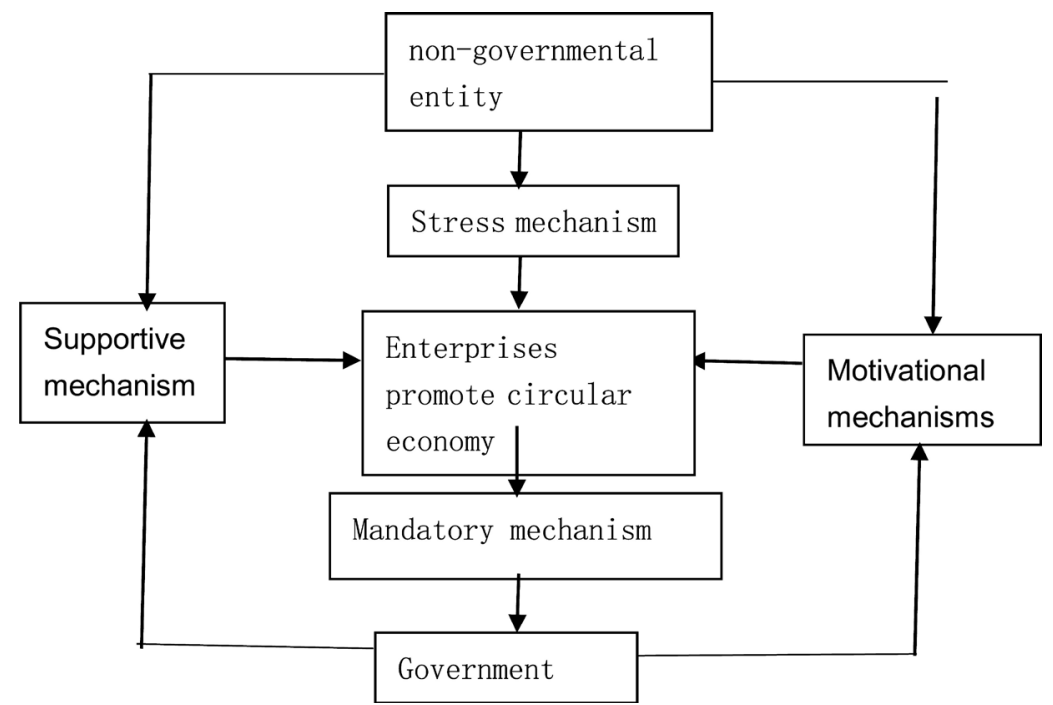

Figure 1. Enterprise business management structure.

development of enterprises for some serious cases [2].

\section{The Role of Technological Innovation in Business Management}

1) It helps to improve the management efficiency of enterprises. The application of scientific and technological innovation can propose more diversified management methods for enterprise management on the traditional basis. These management methods are simpler and more convenient, and can make the internal management of the enterprise operate systematically. At the same time, the use of technological innovation can also carry out management more orderly. On one hand, it can improve the management efficiency of safety management, employee management and file management, on the other hand, it can also improve the management level of enterprises. Digital information management technology is widely used according to the actual situation of business administration. In this way, it can effectively reduce the needs of employees and improve the efficiency of internal management, which plays an irreplaceable role in the future development of enterprises [3].

2) It is beneficial to improve the operating efficiency of the enterprises. Under the influence of the development of market economy, in the current stage of the market, various enterprises show more and more intense trend. In order to occupy a dominant position in this fierce competition, advanced management mode is very important. To improve management efficiency and business efficiency of enterprises, this method can effectively improve the competitiveness of enterprises in the market on the original basis. In addition, companies using technological innovation for business management can strengthen their business extension in the market. In addition, more human and financial resources are invested in the business to create more opportunities for the business management and improve the business efficiency [3] [4]. 
3) It is conducive to the long-term development of enterprises. Market economy is constantly changing. In this context, enterprises will encounter some new problems during their development, which will impact on future development. In order to solve these problems quickly and efficiently and realize long-term development, enterprises must adapt to the changes of society and market economy, and carry out scientific and technological innovation to support the business management of enterprises. It also brings fresh impetus for the development of business management in enterprises through the application of scientific and technological innovation, so that enterprises acquire new survival and development to achieve its sustainable development in the changing market economy [5].

\section{Application Measures of Technological Innovation in Business Administration}

1) Enterprises should increase financial input in scientific and technological innovation. Scientific and technological innovation in the internal business management of enterprises is actually a very time-consuming and labor-intensive project, and it has systematic characteristic. This asks the enterprise besides must have enough professional talent, as well as enough capital. Therefore, enterprises must increase their financial investment in scientific and technological innovation during their development. On the one hand, the enterprises should increase financial investment in scientific and technological innovation-related projects so that the projects can be completed smoothly. On the other hand, they should also increase the salary and remuneration of all talents in scientific and technological innovation on the original basis, and use effective incentive mechanism. The improvement of the working efficiency of scientific and technological innovation employees also provides a continuous impetus for the development of enterprises in the future [6].

2) Enterprises should take the technology innovation of business management as the strategic method of enterprise management. With the development and progress of the society, only by changing their outdated ideas can enterprises effectively carry out scientific and technological innovation in business management. At present, some enterprise managers in China do not have a new understanding of business management, and do not have the concept of scientific and technological innovation. Senior managers should actively establish the idea that "scientific management is the way to rejuvenate the country", strengthen the innovation of enterprise management, update management concepts and strengthen management awareness.

3) Enterprises should establish a professional business management team. Innovation economics Schumpeter pointed out that entrepreneurs are the subject of innovation. This shows that entrepreneurs are the most innovative and influential people. They often break out of the norms creatively, in order to make the business management innovation more efficient. Therefore, to promote en- 
terprise management innovation, the construction of entrepreneur team must be strengthened.

\section{Take Xiaomi as an Example to Analyze the Importance of Technological Innovation in Business Management}

As China has a large population and a huge market, enterprises must pay attention to the importance of technological innovation in business management if they want to survive in the trend. The company Xiaomi has been developing very fast in recent years, which means it has put a lot of effort into business management, just because it has put a lot of effort into business management.

First of all, the management principle of Xiaomi company is: carry out flat management and do less work. Flat management refers to Xiaomi's belief that good employees have a certain degree of self-control. They know what they should do and what they shouldn't do. And Xiaomi's employees all have the urge to make good products. Secondly, Xiaomi has no hierarchy in its organizational structure. The company basically has three levels: at the first level are 7 founders, the second level are department leaders, and the third level are employees. There is no importance difference within the enterprise. Every member is an important link, and plays an important role in his or her position. There is no relationship of interest between each other, but there is a close relationship between each other. They are cooperating to finish the work. At Xiaomi, all but seven of its chief founders do not have their own positions, and they are all technical engineers. They don't get promoted, and the only way they'll get noticed by their boss is to get a raise in salary. In the daily work, there is no interest relationship between employees, which as a result makes the employees feel at ease in work. And they don't think about anything other than work. This kind of management mode without hierarchy will save a lot of comparison links and save time as a result. In the e-commerce war in August 15 ${ }^{\text {th }}, 2012$, it only took Xiaomi less than 24 hours to complete the design, planning, development and supply chain. After going online, the Weibo has been forwarded nearly 100,000 times and the sales volume is nearly 200,000. The Xiaomi company has made use of the Internet as a technological product to sell and publicize, achieving twice the result with half the effort [7].

At the same time, by virtue of the mode of e-commerce booking, Xiaomi achieved to set production according to consumer demands. These sales results Xiaomi achieves are that which traditional retailers could not. To be able to make such sales miracle is not an accident, it is the inevitable result of using science and technology to innovate business management. The design concept of Xiaomi phone is "born for a fever". It is under the trend of this concept that Xiaomi has become successful. Each product USES the world's top science and technology and advanced technology originals.

\section{Conclusion}

With the continuous progress of the society, the cruel competition also follows; 
the crisis and the opportunity exist at the same time. Modern society has entered the era of information and technology. In order to be in line with The Times and occupy a favorable position in the fiercely competitive market, enterprises need to use scientific and technological innovation in their business management so as to improve the level and efficiency of business administration and promote the working of employees in enterprises. Starting from the current situation of enterprises, enterprises should adopt technological innovation in business management for improvement, and combine management mode with social development. Only scientific and technological innovation can lead an enterprise to success. An enterprise should have a management innovation model that suits its own interests [8].

\section{Conflicts of Interest}

The author declares no conflicts of interest regarding the publication of this paper.

\section{References}

[1] Zhai, D.F. and Mu, Y. (2013) Analysis on the Significance of Management Innovation in Enterprise Development. Economic Research Guide, 34, 5.

[2] Xu, G.W. and Chen, S.Y. (2015) Research on the Improvement Path of Technological Innovation Efficiency in Enterprises from the Perspective of Complementary Assets. Science and Technology Management Research, 14, 100-104.

[3] Lin, Y., Zhao, J., Chen, Y.J. and Tang, Y. (2013) Research on the Impact of Just-in-Time Production Mode on Inventory Management of Small and Medium Enterprises. Economic \& Trade Update, 21, 31-40.

[4] Miu, R. (2010) Thoughts on Just-in-Time Mode of Production. Management Observer, 12,10 .

[5] Wang, Q.Y. (2012) Xiaomi Phone's Success Road to Independent Innovation. Modern Marketing, 23, 236-244.

[6] Chen, H.Y. (2015) The Impact of Technology Innovation Mechanism on the Core Competitiveness of Private Enterprises and Its Demonstration. Report of Science and Technology, 22, 261-266.

[7] Yao, Y., Eversb, P.T. and Dresnerb, M.E. (2005) Supply Chain Integration in Vendor-Managed Inventory. Decision Support Systems, 26, 663-674.

[8] Wongnaa, C.A. and Vitor, D.A. (2013) Factors Affecting Loan Repayment Performance among Yam Farmers in the Sene District, Ghana. Agris On-Line Papers in Economics and Informatics, 5, 111-122. 